\title{
French Idiosyncratic Health-Care Reforms, Performance Management and Its Political Repercussions
}

\section{Daniel Simonet}

Management Department, School of Business and Management, American University of Sharjah, Sharjah, United Arab Emirates
Correspondence: Daniel Simonet Management Department, School of Business and Management, American University of Sharjah, PO Box 26666 Sharjah, United Arab Emirates

Tel +97I 65152373

Fax +97। 65584065

Email dsimonet@aus.edu
Context: France has undergone major changes in social policy that made an impact on the health-care sector. The paper reminds readers of the application and shortcomings of the concept of New Public Management (NPM) in the French health system.

Problem: The paper investigates NPM health reforms in France. Reforms aimed at containing costs. What administrative restructuring was implemented? What were reform idiosyncrasies? What were their limitations? Which critical public health emergencies remain?

Methods: We examine the political and economic context of health-care reforms, the rise of the regulatory state, and its core element: the diagnostic-related group (DRG) scale. We critically examine the recentralization of health policy decisions and its impact on care providers and provide an international perspective on reforms.

Results: Reforms put priority on the use of yardsticks and also emphasized regulation and competition but rejected public-private partnerships on the Anglo-Saxon model. Central health authorities regain their authority over health policy decisions, and decentralization was weakened.

Conclusion: Restrictions in public service delivery triggered a general discontent among the population. The political repercussions of reforms eventually crystallized into the Yellow Vest movement.

Keywords: health care reform, health policy, management department, France

\section{Introduction}

In the aftermath of the 2008 recession, drastic health-care reforms were implemented to contain the rise of health-care expenditures in France. These reforms often aimed at regaining control over regions that proved dispendious and had to be bailed out by the central government. The article examines major facets of these reforms: the expansion of the regulatory state, the shift to regulated competition instead of pure competition, and the implementation of centrally defined policy decisions by the Regional Health Agencies (RHA). Reforms emphasized the regrouping of the smaller public health organizations within the larger Regional Health Agencies. The latter implemented top-down accounting mechanisms such as Diagnostic-Related Groups (DRGs) and various incentives (e.g., premiums and penalties) to enable the Central Health Authorities (e.g., the Ministry of health, a High Authority on Health) to "steer" "1,2 the health system "at a distance". 3 This new hierarchical organization concentrated decision-making powers within highlevel civil servants and Regional Health Agencies under the authority of the 
Ministry of Health. Nonetheless, reforms were constrained by administrative path trajectories, earlier decentralization policies of the 1980s, and territorial development plans.

Which forms did this administrative restructuring take? Were there idiosyncrasies in French New Public Management (NPM) reforms? Instead of an open competitive system that was supported neither by the public nor by the medical profession, French authorities embraced regulated competition. The government sets fees for health services. Secondary care providers (hospital, clinics), be they public or private, are incentivized to achieve centrally defined goals. Key NPM recipes such as Public-Private Partnerships had outcomes below expectations. Private and public care providers coexist, but there is a greater differentiation between them. Reforms emphasized yardstick competition, a benchmarking of hospitals, a quantification of outputs (e.g., volume and types of medical procedures performed) rather than outcomes (e.g., patient health). This restructuring also relied on performance indicators to govern health care actors "at a distance". ${ }^{4}$ Were there unanticipated limitations considering the specificities of the French health system? Geographic disparities in health care are on the rise, and the impact of austerity measures is evident. Similar reforms in other public areas proved taxing for citizens, street-level bureaucrats, and frontline workers. Society is increasingly fragmented, and secessionary forces on the economic and geographic plan triggered some of the worst riots in contemporary France. Hence, reiterated calls for community consultation and citizen participation.

\section{Methodology}

We opted for a descriptive approach followed by a discussion to take stock of NPM implementation. The article will inform the reader about NPM's management recipes (e.g., yardstick competition, top-down control mechanisms, Diagnostic Related Groups, public-private partnerships) and elusive goals (e.g., efficiency, performance), assess their impact on health services delivery and patients. We used secondary academic and professional sources to examine the surge of the regulatory state, how NPM reforms reshaped the health system and hurt public values. Overall, the article gives an outline of the overall NPM key precepts.

\section{The Health Care Regulatory State and the Rise of the DRGs}

In contrast to the NPM-endorsed dispersion or decentralization of public organizations, ${ }^{5}$ the concentration and verticalization of health policy decisions were a core element of French NPM reforms. As in education ${ }^{6}$ and policing, ${ }^{7,8}$ there was the assumption that the health-care system could be "steered at a distance" 4,9 through incentives and regulations. ${ }^{10-13}$ The aim was to strengthen or reassert the "center"14 (e.g., the Ministry of Health) at the expense of the operating core (e.g. physicians and their associations) and street-level bureaucrats to regain authority over multiple fragmented public health organizations, local welfare agencies such as the Regional Directorates of Health and Social Affairs (Directions Régionales des Affaires Sanitaires et Sociales) (DRASS), the Departmental (or County-level) Directorates of Health and Social Affairs (Directions Départementales des Affaires Sanitaires et Sociales) (DDAS) and the regional sickness funds. In the aftermath of the decentralization laws of 1982, multiple local public health organizations, regional sickness funds, powerful local and corporate business interests, city mayors (e.g. half of parliamentary representatives or senators are city mayors) were often at odds with each other and used their networks to bypass the decisions made by the Ministry of Health. This fragmentation hampered the attribution of responsibilities, made it difficult to know whom to blame and for what, and led to duplications of social and health services. Moreover, it created inflationary pressure, sapped the authority of the Ministry of Health, and prevented the implementation of consistent policies across the country. In response, the Ministry of Health created the Regional Hospital Agencies in 1996, and in 2010 regrouped all health policy decisions within the Regional Health Agencies that replaced the Regional Hospital Agencies, strengthened its vertical control over the executive branch via the appointment of key staff (e.g., the Ministry of Health appoints the director of the Regional Health Agencies; the former appoints the hospital director who hire the heads of the hospital departments ...). The Ministry of Health also endeavored to monitor public health organizations and strengthen its capacity to reform the entire health system via incentives. These incentives included pay-forperformance mechanisms, patient and volume targets for hospitals, penalties and premiums for care providers, activity-based accounting mechanisms, guidelines, protocols, and other economic tools such as cost and benefit analysis. Regional Health Agencies contributed to the birth of a new technostructure that imposed a higher burden on the medical profession. Physicians' prerogatives were taken away by health-care bureaucrats and the 
administrative elite. ${ }^{15}$ Evidence-based decision-making led to the delisting of pharmaceutical drugs and medical procedures that offer too few benefits for patients. Scientific management extended to medical practice to align hospital compensation with their actual activity. A new Taylorist approach presumed that each medical procedure could be divided into smaller, simpler processes to be compensated separately via a DRG set fee. The DRG fee schedule eventually replaced the lump sum that was traditionally allocated to every hospital based on past expenditures and local demographic characteristics.

The DRG fee schedule is not set by the market (e.g., care providers or patients) but by the Ministry of health based on a sample of participating hospitals. Despite little consultation with the medical profession, the DRG scale has applied to all public and private hospitals, even if their service offering and missions differ. The DRG scale also heralded the rise of the audit society in health care. ${ }^{16}$ By law, every hospital must have an IT department, store the patient medical file, and code his/her medical procedures into a specific DRG category that will determine the hospital's compensation. Moreover, it allows the authorities to track the number of procedures and identify outlier hospitals with a higher rate of surgeries that would indicate physician-induced demand. ${ }^{17,18}$ DRGs are also used in epidemiology to identify disease incidence ${ }^{19,20}$ and track treatment patterns across the country. The National Health Data system is primarily centered around the Statutory Health Insurance database, which contains approximately 1.2 billion yearly records with prescriptions and consultation data ${ }^{21}$ in hospitals that provide acute, psychiatric, and long-term care.

In theory, the DRG fee schedule reflects the actual hospital activity, which will determine its compensation with greater accuracy than the former system that was based on governmental grants that depended on the bargaining power of the hospital and other stakeholders such as city mayors. Incidentally, it prompts care providers to compete for patients to secure an income, which, at least in theory, will reduce patient waiting times. Public hospitals reduced the patient length of stay by $4.4 \%$ to free up beds for new patients. ${ }^{22}$ Like corporate benchmarks, the DRG fee schedule also incentivizes hospitals to control expenditures. If the cost of treating a particular ailment exceeds the DRG set limit, the hospital - not the government covers the gap. If the costs are lower, it pockets the difference. The DRG fee schedule is not exempt from limitations. While this compensation mechanism works relatively well for standard operations where outcomes are predictable and consistent, it is less suitable in uncertain environments such as health care. Medical outcomes are sometimes hardly predictable, as they vary from one patient to another depending on demographic factors, case severity, comorbidities (e.g, chronic diseases), access to health services, and the environment, which renders the comparison of care providers more difficult. ${ }^{23}$

\section{French Idiosyncratic Reform Orientations Regulated Competition}

Unlike other sectors (e.g., aviation, the telecommunication sector, management of highways) that were deregulated and privatized with relative ease and without much opposition from the public, the French health-care system experienced neither deregulation nor privatization. Implementation of market-based reforms is shaped by sector-specific differences that reflect the diversity of professional communities (e.g. physicians, the Welfare elite, the technocracy). These interact with reform processes and use their power to influence the latter. ${ }^{24}$ While physician's prerogatives have receded and government reforms contributed to a weakening of physicians' trade unions, these remain influential at the local level (e.g., in many rural areas, the city mayor is often a retired physician), and could not be ignored. Unlike the split between the commissioning and the provision of health services in the British NHS, ${ }^{25,26}$ French physicians were hardly willing to play one care provider (e.g., hospitals, laboratory) against another to demand better-contracting terms such as faster services for patients or lower costs for the Social Security. In contrast to the British general practice Consortium $^{27}$ and fundholding practices ${ }^{28}$ that represent several thousand patients and thus exert some bargaining power when negotiating with care providers, French solopractice physicians lack sufficient clout to make any difference during fee negotiation with care providers. Hence, the NHS quasi-market approach in the procurement and delivery of health services ${ }^{29}$ did not apply to France. French physicians supported neither marketization (e.g., a competition of care providers) nor deregulation.

First, competition could not possibly exist in many rural areas and the poorer suburbs of Paris due to a lack of care providers and academic health centers in particular (there are only 30 across the country). Secondly, the professional values of French physicians are not conducive to 
competition. Unlike British fundholding doctors ${ }^{30}$ and American physicians who see themselves as entrepreneurs, French physicians have little interest in health-care management, let alone in a health-care entrepreneurial model, though it is changing, as there is a greater awareness of the costs of health services. As for the US-modelled "Managed Competition" that led to the economic concentration of Health Maintenance Organizations (HMOs) and the formation of nationwide hospital networks, the French programmatic elite ${ }^{31}$ was well aware that outcomes ${ }^{32}$ were below expectations on many dimensions, as the US Managed Care experience satisfied first and foremost corporate interests (e. g., HMOs, hospitals, ...) rather than patients' needs. National health-care expenditures would have been higher if French care providers had engaged in a US-modelled medical arms race to attract patients. Moreover, perfect competition in health care with multiple actors such as public and private hospitals vying for patients would have defeated the purpose of reforms: to regain control over poorly coordinated public health organizations that were often at odds with each other and sapped the authority of the Ministry of Health. ${ }^{33}$ Therefore, there was more - rather than less - government intervention ${ }^{34}$ via regulations and recommendations, as guidelines from the High Authority on Health attest; more enforcing techniques, including premiums and penalties, which paved the way for the rise of the French "regulatory state". ${ }^{35}$ Reforms were designed to reassert the center (e.g., the Ministry of Health) at the expense of the professional bureaucracy (e.g., hospitals) and its operating core (e.g, hospitalist physicians) to contain the "medicalization" of the French society. Reforms also aimed to downsize the French hospital sector, which represented a higher share of health expenditures than other OECD countries. ${ }^{36}$ However, the costs of the reforms were underestimated. This is not unique to France. ${ }^{37}$ In all likelihood, they exceeded the cost of the much-feared, but never defined "medicalization" of the French society.

\section{Anglo-Saxon Consolidation vs. French Dispersion}

Anglo-Saxon reforms ${ }^{38,39}$ have traditionally emphasized the consolidation of care providers on the corporate model. ${ }^{40} \mathrm{In}$ contrast, there was never an appetite for economies of scale and a greater economic concentration of either care providers or supplementary insurers in the French health-care system. Though central health authorities demanded further integration and coordination of local care providers and regulatory bodies (e.g., the prerogatives of fragmented public health organizations were regrouped within the Regional Health Organizations), they never allowed the formation of hospital networks that would be powerful enough to challenge the bargaining power of the French Social Security during fee negotiation. Earlier decentralization policies (i.e. the 1982 Decentralization Act) also hampered the quest for economies of scale. ${ }^{41}$ Moreover, previous attempts to merge hospitals proved more expensive than anticipated.

On top of that, add French idiosyncrasies. By law, emergency services that are exclusively provided by public hospitals must be available to every citizen within 30 minutes. The resulting territorial dispersion of public hospitals does not facilitate their regrouping into larger entities. It also puts patients at greater risk (e.g. low-volume hospitals have poorer health outcomes than high-volume hospitals). Moreover, devolution that characterized the French administrative apparatus ${ }^{42}$ in the aftermath of the 1982 Deferre law and hospital's positive externalities such as territorial development in regions prevented their regrouping. Even when state budgets were set aside for hospital mergers, physicians and the public continued to oppose them. Citizens are also firmly attached to their local care provider, even more so as it is often the largest local employer, particularly in rural areas.

\section{PPP Rejection in France}

Public preferences also shaped policies. The rejection of PPPs is another French idiosyncrasy. While British privatization programs went steady ${ }^{43}$ for ideational and political reasons, ${ }^{44}$ French citizens did not support the privatization of public hospitals, ${ }^{8}$ unlike other state-run services such as postal services, telecommunications or airline transportation that were denationalized with relative ease (e.g. France Telecom in 2004; Air France in 1999). In contrast to the UK, the French government did not view delegation to private actors as a means to create jobs in recessionary times. The public did not perceive hospitals as performing below expectations or too expensive to justify a radical change of ownership. Neither did it expect privatization to lower costs (e.g. health services were already free-of-charge for users) or prevent service disruption (e.g. strikes were a rare occurrence in public hospitals), as in the airline or telecommunication sector. There was never the perception that the public health sector had failed, unlike other core public areas such as policing or unemployment, ${ }^{8}$ and that privatization could be the solution. Moreover, privatization of care providers would have defeated the primary goal of reforms: to reinstate the Central Health Authorities' control 
over local health-care actors. Despite public opposition, the delegation of health services to private actors - rather than their privatization - extended to France, as exemplified by the rise of private care providers and a handful of short-lived PPPs. The 2007 Hospital Plan supported PPPs, which consisted of a private hospital's long-term lease with a purchase option. French PPPs, however, proved disappointing, ${ }^{45}$ as exemplified by the PPP for the construction of the Sud-Francilien Hospital. ${ }^{39}$ In retrospect, France did not satisfy the preliminary conditions for a successful PPP. ${ }^{46}$ Transparency was lacking, ${ }^{47}$ and the government's more significant revenues eventually reduce its appetite for PPP. ${ }^{48}$ Durant $^{49}$ (1998) also explored the accountability challenges of privatization. "When accountability mechanisms are faulty or non-existent, privatization can fail" ${ }^{, 50}$ due to a considerable distance between the central health authority and the construction companies. While there are exceptions, as exemplified by Portugal, where PPP hospitals display performance levels similar to those of public hospitals, ${ }^{51}$ PPPs often failed to deliver value for money. ${ }^{52}$ The French General Accountability Office criticized PPP's higher costs. In the UK, too, the total government resources going to Private Finance Initiative (PFI) providers have been estimated at far more than the public sector borrowing option. ${ }^{53}$ Moreover, private actors monopolized and privatized public knowledge, created dependencies (e.g. regarding the maintenance of facilities), eroded tacit knowledge that has been built over decades, and weakened public accountability ${ }^{54}$ since the blame game was often being played between the health authorities and the construction companies. For one partner, privatization could become a rent-seeking behavior. ${ }^{55}$ Overall, French PPPs created additional costs for Social Security and taxpayers, ${ }^{56}$ which triggered a media backlash. PPPs subsequently moved to other public areas that faced less public and media scrutiny, such as airport management and the prison system.

While PPPs failed, a dual system emerged. The shrinking of the public hospital sector, as evidenced by the closure of the smaller hospitals and the reduction in the number of hospital beds, paved the way for a vibrant private hospital sector. A cottage industry comprising a myriad of private clinics coexist with public care providers. One thousand seven hundred private clinics account for $25 \%$ of hospital services. For surgeries, the private sector represents about $60 \%$ of all hospital admissions. ${ }^{22}$ There are 226,000 physicians in France. Forty-five percent of them are self-employed. But the substitution of public operators by private providers, which was neither explicitly nor publicly debated, has limitations. While private hospitals can replace public hospitals in cities, even more so for standard operations, this is hardly feasible in rural and suburban areas. Private hospital chains are reluctant to set up facilities in the countryside due to difficulty attracting qualified staff. The 800 regional medical centers ("Maisons de santé") can not satisfy public demand, as they provide primary rather than specialized care. Therefore, the longstanding issue of medically underserved areas remains.

\section{Discussion}

\section{Yardsticks and Other Performance Indicators: A Critical Assessment}

Difficulties and limitations associated with the DRG scale have revived the debate on the use of performance indicators in public organizations. Muller ${ }^{57}$ (2018) argues that we must counter the systematic use of performance indicators as the sole yardstick for judging the performance of individuals, institutions, and public organizations. Indicators create their own set of problems that are addressed via more rules and regulations. For instance, the latest DRG scale added five disease severity levels. Indicators are not exempt from biases, as they often serve the goals (e.g. austerity) of their architect, including the Ministry of Health and the Central Health Authorities. The latter shall meet the EEC agenda of fiscal discipline ${ }^{58-61}$ that imposes a maximum national budget deficit of $3 \%$ of GDP. In France, budget cuts affected first and foremost education and health care, which account for $18 \%$ of the French GDP. ${ }^{62}$ These cuts were at the expense of public needs such as access, equity, and quality. Access is no longer a priority, as exemplified by the termination of maternity hospitals, the closure of smaller hospitals in rural areas and emergency services in city centers, and the suppression of beds in hospitals (over 100,000 between 1993 and 2018) as well as in intensive care units. ${ }^{63}$ DRGs do not provide equity in funding, as payment remains the same despite considerable differences in the hospital's geographic environment and local pool of patients. As for quality, novel compensation mechanisms do not factor in the quality of care provided to patients, as payments to hospitals do not reflect the patient's health at discharge. Yardsticks competition, accounting reforms such as DRGs, hospital benchmarking via IT systems that collect patient data, financial incentives designed to manage the health system at a distance were costly endeavors for taxpayers, which lead to a critical assessment of the Big Data 
concept. France dedicates $7 \%$ of its health expenditures (about 15 billion euros) to the management of its health system. This is twice as high as the OECD average. ${ }^{36}$ The costs of the auditing techno-structure are high in France. The Regional Health Agencies (RHAs) employ more than 9,000 agents (84\% of them are government employees). Comprising diverse professions (e.g. lawyers, engineers, geographers), the RHA strengthened the state technocracy ${ }^{64}$ at the expense of the operating core (e.g. the physicians and nurses). In 2017, the RHA of the region of Auvergne-Rhône-Alpes employed 1,000 employees with an annual budget of $€ 490$ million for a population of 7.7 million. ${ }^{36}$ The RHA for Paris and its suburbs, the third-largest Agency in terms of population covered, employs 650 health-care professionals for 6 million residents. Out of the 18 billion euros spent on the local healthcare system, it disbursed more than 4 billion euros per year to care providers. Due to mergers, the number of RHAs fell from 26 to 17, including 13 in metropolitan France and 4 in French overseas territories.

While performance indicators can be applied relatively straightforwardly when public services can be divided into smaller repetitive and straightforward tasks that are easily quantifiable (e.g. mail delivery, transportation sector, public infrastructure ...), this is harder to achieve in healthcare due to the oversimplification that the assessment of complex medical procedures requires. Moreover, multiple concurrent definitions of what constitutes a well-performing health system make the selection of performance indicators more susceptible to bias. Due to the limited individual rationality, ${ }^{65}$ the first observed bias has been the focus on one of the World Health Organization's four dimensions of the health-care system (i.e. quality, fairness, cost, efficiency). Performance assessment in France has often implied selecting one or two (e.g. cost, efficiency) indicators at the expense of others (e.g. access including waiting times, availability of beds in intensive care units and expensive medical equipment such as MRI) to comply with the National Health Expenditure Target (Objectif National des Dépenses d'Assurance Maladie - ONDAM) voted every year by the Parliament. Accountability is not necessarily greater. In France, in particular, quality indicators are missing. They only exist for nosocomial infections. Moreover, there are only estimates of the number of medical errors. Germany and the UK are the only countries to emphasize quality improvements and adopt financial penalties for hospitals if the patient is readmitted within days for the same condition, which would indicate that they were discharged too early.

\section{French Idiosyncratic Features: An International Perspective}

What can other health systems learn from the French transition from a predominantly public system to a hybrid public/private system under NPM influence? What are French NPM idiosyncratic features? The hierarchical organization of other public health systems like Germany, Spain, and Italy differs from France. Spain, ${ }^{66}$ Germany, ${ }^{67}$ Italy, ${ }^{68}$ and Canada are all decentralized health systems. In contrast, France pursued a recentralization agenda (i.e. a concentration of funding decisions within the Ministry of Health and a regrouping of policy planning decisions within the Regional Health Agencies) and verticalization (e.g. top-down compensation mechanisms, including premiums and penalties for care providers, control of the Regional Health Agencies by the Ministry of Health), which contrasts with NPM-endorsed decentralization policies on funding and policy planning in foreign exemplars. In Portugal too, the recession and the need to cut health-care expenditures weakened the decentralized model of health administration. ${ }^{69}$ France also strengthened the regulatory arsenal to manage care providers from a central administrative apex and rejected British-modelled public-private partnerships. Another difference is that the divide between the public and private sectors in France is not as strong as in Canada, the UK, or Italy. Unlike Canada, French physicians are not prohibited from working for both public and private care providers. French health authorities created Health Care Groups or "Groupement de coopération sanitaire" to allow private and public hospitals to share facilities. ${ }^{22}$ However, that cooperation is far from adequate, as the Covid Pandemic later revealed. Compared with the UK, where private medicine constitutes a niche market ( $£ 32$ million out of $£ 197$ million in 2017), ${ }^{70}$ private medicine in France plays a more substantial role, and unlike the UK, is not restricted to certain specialties such as orthopedics or cataract surgery where long waiting list exists. ${ }^{71}$ Moreover, French NPM recipes do not align with the NPM Anglo-Saxon pro-competitive agenda. Public and private care providers complement rather than compete with each other for patients. Private hospitals are located next to - sometimes within - public hospitals. Individual physicians routinely rent public hospital facilities for their private practice. As a source of prestige, public - rather than private - hospitals remain a major draw for the French medical elite. As in the UK and Italy, French public hospitals are also in charge of training physicians (i.e. all 30 academic health centers are public), providing them with opportunities to handle more complex patient cases and to do research, which is nearly non-existent in 
private care providers. Payments for private health services also differ. Unlike Canada that prohibits patients from buying private insurance or paying out of pocket for publicly covered services, the French Social Security pays for services delivered by all care providers, private and public. Unlike the UK, where $75 \%$ of private healthcare is funded by private health insurance, French private practices can bill the Social Security for publicly covered services. Patients (or their supplementary insurance) only pay for the higher costs of health services provided by private practices. The role of supplementary insurance is also different. Unlike Canada that effectively prohibits patients from buying private insurance, and the UK, where only $10 \%$ of the population is privately insured, all French citizens or their employers are encouraged via a variety of tax incentives to take up private supplementary insurance to cover the higher costs of private care providers. Currently, $96 \%$ of French citizens are enrolled in some supplementary insurance. $^{72}$

While some essential services such as emergency services remain public, there is a greater segmentation of care providers rather than competition between them. In both France and the UK, small fragmented private clinics alleviates the waiting lists for low-risk non-urgent care, offers follow-up and rehabilitation services for patients, and provides the more standard and routine medical procedures. Nonetheless, the private sector faces better prospects in France than in the UK and Canada. Unlike the UK, where the "repatriation" of NHS services has led to declining revenues of private hospitals, ${ }^{73,74}$ the provision of health services is unlikely to return to the public realm in France, as it will contradict the remarkedly resilient pro-market reform agenda of all successive governments. This also reflects France's adhesion to the EU marketization agenda as well as different societal values. French support for public hospitals is nowhere close to the attachment of British citizens to their NHS. Finally, French physicians in private practices are equally dispersed across the territory. This contrasts with the $\mathrm{UK}$, where private medicine is essentially concentrated in London, and with Southern Italy, where patients switch to private insurers to afford better-equipped private care providers. $^{75}$

\section{Austerity, Social Demotion, and Their Political Repercussions}

In healthcare, higher patient copayments, elderly abuse in private retirement pension homes, ${ }^{76}$ the closure of maternity hospitals in rural areas, ${ }^{77}$ the shutting-down of emergency services in city centers, and the closure of hospitals that perform too few operations in rural areas, are significant sources of discontent among the public and the medical profession. A new definition of the medically underserved areas highlights the extent of the problem. While the previous definition of the underserved regions was based on the number of doctors per inhabitant, the new one is a function of the population's health-care needs. Considering population demographic characteristics, traveling time to general practitioners, activity volume, and other criteria, 12 million inhabitants or about $18 \%$ of the population live in medically underserved areas compared with just six million in the former classification. ${ }^{78}$ 4.4 million residents of Paris and its suburbs, representing $37 \%$ of the population in these areas, do not have proper GP access.

What can we expect from now on? There has been little progress on major issues such as access, waiting lists, and the underfunding of EDs. The reduction in the number of public hospital beds (over 100,000 were suppressed over the last 20 years), the resulting long waiting lists, and the overcrowding of emergency services remain significant sources of discontent. Similar outcomes were observed in other countries ${ }^{79}$ regarding access and other public sectors in France that experienced NPM reforms. The termination of the smaller post-offices; ${ }^{80}$ the decommissioning of the less profitable railway lines and train stations, ${ }^{81}$ the merger of the courts of justice and military bases all contributed to the death of rurality and the rise of territorial inequality. ${ }^{82}$ Under the guise of "intercommunality", the closure of classrooms and mergers of the smaller rural public schools (400 schools were closed in 2019) ${ }^{83}$ generate immediate savings for the local government but forced children to travel further to attend schools while being separated from their siblings. These led to today's populist reaction against top-policy-makers and experts ${ }^{84}$ exemplified by the Yellow vest movement.

While the sudden rise of oil prices was the triggering point of the 2018 Yellow Vest movement, popular discontent has been simmering for years due to the rarefaction of public services, downward social mobility, and the demotion of the French middle class. ${ }^{85}$ For the vast majority of citizens, liberal democratic citizenship will always be second-class or plebeian citizenship. ${ }^{86}$ Contrary to Green, ${ }^{87}$ who argues that plebeian citizens must protect their happiness by fostering a critical indifference toward political life and finding solace outside conventional political spaces or the public sphere (extrapoliticism), for instance, via friends and associations, the Yellow Vest movement shows otherwise. Its combination of both the far left and the far right, two traditionally opposed political parties - a first in the history of French protests - can be 
analyzed under the light of Proudhon ${ }^{88}$ (1863), the founder of the mutualist philosophy. Proudhon witnessed the Parisian revolution of 1848 and theorized social movements that were without a leader (e.g. horizontal insurrection), as was the Yellow Vest movement. He believed that people's representatives were out of touch with ordinary citizens, promoted federalism instead of re-centralization, and supported a direct democracy. He sought to restrain the regulatory state and the Jacobinist tradition. Unlike the Anglo-Saxon approach, French Jacobinism should not be construed as radical left-wing revolutionary politics but as a consolidated republican state that believes in the centralization of decision-making powers as a necessary condition for effective reforms. ${ }^{89}$ Hence, today's reiterated calls for self-regulation at the commune, district, and regional level; for a bottom-up rather than top-down democracy that will encourage popular initiatives, and demands for popular consultations on the Swiss model, despite the weaknesses of referendums. ${ }^{90}$ Secession forces are on the rise, economically, culturally (e.g. the French archipelago), ${ }^{91,92}$ socially and politically, as exemplified by the fragmentation and renewal of the French political landscape. For instance, the rise of the National Rally (formerly the National Front) and the Green Party's resurgence in the 2019 European and 2020 municipal elections were at the expense of traditional parties such as the right-wing and the socialist party. Compounding factors include an increasingly polarized republic, ${ }^{93}$ a loss of institutional legitimacy (e.g. the Senate is accused of amending parliamentary laws to preserve the interests of the French business and political oligarchy at the expense of citizens), a slew of scandals involving top-level civil servants and politicians (e.g. the Benalla and Fillon scandals), and an erosion of citizens' trust and satisfaction. ${ }^{94}$ President Hollande's ratings were the lowest of all French presidents. Macron has faced the worse riots since May 1968. However, this societal and economic fragmentation is unlikely to end vertical and centripetal forces that drive the restructuring of the French administration.

Citizens and their representatives felt increasingly sidelined, despite France having one of the highest number of citizen's representatives per inhabitant: 1,158 representatives spread across the National Assembly, the Senate, and the Economic, Social and Environmental Council, and another 511,000 representatives in regional, communal, and county (“department")-level assemblies. These shortcomings had political repercussions, as exemplified by the defiance of the French middle-class ${ }^{95}$ and the rise of the Yellow Vest movement. The inability to listen to citizens prompted Andolfatto \& Labbe $^{96}$ to proclaim that social democracy has failed in France. These dysfunctions are compounded by market failures and anxiety of various participants (e.g. the public, the medical profession) against NPM inroads, not just in health care but in many other public areas.

\section{Conclusion}

Despite progress in medical technologies, physicians' and citizens' trust in the health system has eroded. There is a growing gap between the state's achievements and citizens' expectations. The government-endorsed policies (e. g. competition, regulation, fiscal discipline ...) are no longer in line with the values of the public. Reforms allowed the government to regain control over the health sector as a whole, not just hospitals. We note the remarkable prediction of Deleuze ${ }^{97}$ regarding the rise of the society of control, particularly in health care; from the molding ("disciplining") of workers ${ }^{98}$ to an open-ended process of "modulation" or "steering" from a distance. 99 However, French institutional and administrative traditions prevented NPM from achieving some of its original goals such as greater democratic participation. The government relied on NPM to recentralize decision-making powers, reassert its capacity to reform and regain control over payers (e.g. Social Security and supplementary insurers), care providers, and local public health organizations. Moreover, transparency, another initial NPM goal, is not necessarily higher, as conflicts of interest between the medical profession, public and private care providers continue to affect performance reporting. ${ }^{100}$ Governing at a distance, biases in performance indicators, and more generally, the withdrawal of core public services aggravated public discontent. These have had political repercussions, such as the unanticipated rise of the National Rally (formerly the National Front). Finally, this analysis opens new avenues in cross-country research, such as comparing the French experience with other continental EU countries like the Czech Republic ${ }^{101}$ that pursues similar centralization strategies for efficiency reasons. ${ }^{102}$

\section{Funding}

This research did not receive any specific grant from funding agencies in the public, commercial, or not-forprofit sectors.

\section{Disclosure}

The author reported no conflicts of interest for this work. 


\section{References}

1. Ferlie E. The new public management and public management studies. In: Oxford Research Encyclopedia of Business and Management. New Public Management; 2017.

2. Bezes P. The "steering state" model: the emergence of a new organizational form in the French Public Administration. Sociol Trav. 2007;49:e67-e89. doi:10.1016/j.soctra.2007.10.002

3. Bezes $\mathrm{P}$, Demazière $\mathrm{D}$, Le Bianic $\mathrm{T}$, et al. New public management and professionals in the public sector. What new patterns beyond opposition? Sociologie du Travail. 2012;54(Suppl. 1):e1-52.

4. Gally N. Executive shift or Steering at a distance? Rev Fr Sci Polit. 2018;68(4):691-715. doi:10.3917/rfsp.684.0691

5. Lægreid P. Still fragmented government or reassertion of the centre? In: Transcending New Public Management. Routledge; 2017:29-54.

6. Lemke T. 'The birth of bio-politics': Michel Foucault's lecture at the Collège de France on neo-liberal governmentality. Econ Soc. 2001;30(2):190-207. doi:10.1080/03085140120042271

7. Guild E, Bigo D. Policing at a distance: Schengen visa policies. In: Controlling Frontiers. Routledge; 2017:233-263.

8. Bonnet F, De Maillard J, Roché S. Plural policing of public places in France. between private and local policing. Eur $J$ Policing Stud. 2015;2(3):285-303.

9. Bezes P, Demazière D, Le Bianic T, Paradeise C. New public management and professionals in the public sector. What new patterns beyond opposition? Sociol Trav. 2012;54(Suppl. 1):e152. doi:10.1016/j.soctra.2012.07.001

10. Laval C. Foucault, Bourdieu Et La Question Néolibérale. Paris, France: La Découverte; 2018.

11. Galič M, Timan T, Koops BJ. Bentham, Deleuze and beyond: an overview of surveillance theories from the panopticon to participation. Philos Technol. 2017;30(1):9-37. doi:10.1007/ s13347-016-0219-1

12. Felix $\mathrm{C}$, Vérillon P. Pilotage à distance de l'activité par les dispositifs: dilemmes professionnels, pouvoir d'agir et renormalisation du milieu de travail; 2017.9-30. Avaliable from: https://hal.archives-ouvertes.fr/ hal-01755843/document. Accessed June 4, 2021.

13. Cole A. Governing and Governance in France. Cambridge: Cambridge University Press; 2008.

14. Dahlström C, Peters BG, Pierre J. Steering strategies in western democracies. In: Steering from the Centre. University of Toronto Press; 2017:263-276.

15. Bergeron H, Nathanson CA. Construction of a policy arena: the case of public health in France. $J$ Health Polit Policy Law. 2012;37(1):5-36. doi:10.1215/03616878-1496002

16. Parker LD, Jacobs K, Schmitz J. New public management and the rise of public sector performance audit. Account Audit Account J. 2018;32:280-306. doi:10.1108/AAAJ-06-2017-2964

17. Cromwell J, Mitchell JB. Physician-induced demand for surgery. $J$ Health Econ. 1986;5(4):293-313. doi:10.1016/0167-6296(86) 90006-8

18. Green J. Physician-induced demand for medical care. J Human Resources. 1978;13:21-34. doi:10.2307/145246

19. Cottenet J, Dabakuyo-Yonli TS, Mariet AS, Roussot A, Arveux P, Quantin C. Prevalence of patients hospitalised for male breast cancer in France using the French nationwide hospital administrative database. Eur J Cancer Care (Engl). 2019;28:e13117. doi:10.1111/ecc. 13117

20. Casez P, Fauconnier J, Jorgensen L, et al. Longitudinal DRG-based survey of all-cause and pneumococcal pneumonia and meningitis for inpatients in France (2005-2010). Med Mal Infect. 2015;45(1112):446-455. doi:10.1016/j.medmal.2015.10.004

21. Or Z. Investment in big data; 2015. Available from: https://www. hspm.org/countries/france25062012/countrypage.aspx. Accessed June 4, 2021
22. Choné P. Competition policy for health care provision in France Health Policy (New York). 2017;121(2):111-118. doi:10.1016/j. healthpol.2016.11.015

23. Ferreira D, Marques RN. A pay for performance in health care: a new best practice tariff-based tool using a log-linear piecewise frontier function and a dual-primal approach for unique solutions. Operation Res. 2019;2019:1-46.

24. Turner S, Lourenço AN, Allen P. Hybrids and professional communities: comparing UK reforms in healthcare, broadcasting and postal services. Public Adm. 2016;94(3):700-716. doi:10.1111/ padm. 12256

25. Hudson B. Public and patient engagement in commissioning in the English NHS: an idea whose time has come? Public Manag Rev. 2015;17(1):1-16. doi:10.1080/14719037.2014.881534

26. Gore O, McDermott I, Checkland K, Allen P, Moran V. Discretion drift in primary care commissioning in England: towards a conceptualization of hybrid accountability obligations. Public Adm. 2020;98(2):291-307. doi:10.1111/padm.12554

27. Maclean $\mathrm{H}$. The general practice Consortium: the future of fundholding? In: Future Options for General Practice. 2018:93-108.

28. Dowling B. GPS and Purchasing in the NHS: The Internal Market and Beyond. Routledge; 2017.

29. Osipovic D, Allen P, Sanderson M, Moran V, Checkland K. The regulation of competition and procurement in the National Health Service 2015-2018: enduring hierarchical control and the limits of juridification. Health Econ Policy Law. 2020;15(3):308-324. doi:10.1017/S1744133119000240

30. Ham C. Management and Competition in the NHS. CRC Press; 2018.

31. Genieys W, Smyrl M. Inside the autonomous state: programmatic elites in the reform of French health policy. Governance. 2008;21 (1):75-93. doi:10.1111/j.1468-0491.2007.00386.x

32. Ramamonjiarivelo Z, Weech-Maldonado R, Hearld L, Pradhan R, Davlyatov GK. The privatization of public hospitals: its impact on financial performance. Med Care Res Rev. 2020;77 (3):249-260. doi:10.1177/1077558718781606

33. Pierru F, Rolland C. Bringing the healthcare state back in: political issues of integration through merger: the case of regional health agencies. Revue Française de Science Politique. 2016;66 (3-4):75-99.

34. Brown LD, Jacobs LR. The Private Abuse of the Public Interest: Market Myths and Policy Muddles. University of Chicago Press; 2009.

35. Majone G. The Evolution of the Regulatory State. Routledge Handbook of Risk Studies; 2016.

36. Grimaldi A. Les hôpitaux en quête de rentabilité: à quel prix ? Revue Du MAUSS. 2013;41(1):25-33. doi:10.3917/rdm.041.0025

37. Nunes A, Ferreira D. The health care reform in Portugal: outcomes from both the new public management and the economic crisis. Int $J$ Health Plan Manag. 2018;34(1):196-215. doi:10.1002/hpm.2613

38. Gaynor M, Laudicella M, Propper C. NHS hospital mergers: what benefits? Czasopismo Ekonomia I Zarzadzanie. 2016;(2):57-59.

39. Gaynor M, Laudicella M, Propper C. Can governments do it better? Merger mania and hospital outcomes in the English NHS. $J$ Health Econ. 2012;31(3):528-543. doi:10.1016/j. jhealeco.2012.03.006

40. Ferlie E, Parrado S. Strategic management in public services organizations: developing a European perspective. In: The Palgrave Handbook of Public Administration and Management in Europe. London: Palgrave Macmillan; 2018:101-119.

41. Porter ME. Competitive Strategy. Free Press; 1980.

42. Bezes P, Le Lidec P. Politiques de la fusion: les nouvelles frontières de l'État territorial. Revue Française de Science Politique. 2016;66(3):507-541. doi:10.3917/rfsp.663.0507

43. Powell M, Miller R. Seventy years of privatizing the British National Health Service? Soc Policy Admin. 2016;50(1):99-118. doi:10.1111/spol.12161 
44. Heffernan R. UK privatisation revisited: ideas and policy change, 1979-92. Polit Q. 2005;76(2):264-272. doi:10.1111/j.1467923X.2005.00678.x

45. Cléry-Melin P. Partenariat public-privé: enjeu d'une restructuration nécessaire. L'information Psychiatrique. 2019;95(1):7-14.

46. Kirat T, Marty F. Le contrat de PPP à l'épreuve des contentieux: retours d'expériences sur le cas français; 2017. Available from: http:/www.chaire-eppp.org/wp-content/uploads/2018/04/KiratMarty-Mars2017.pdf. Accessed June 4, 2021.

47. Compin F. Tax fraud: a socially acceptable financial crime in France? J Financial Crime. 2015;22(4):432-446. doi:10.1108/ JFC-09-2013-0052

48. Rosell J, Saz-Carranza A. Determinants of public-private partnership policies. Public Manag Rev. 2019. doi:10.1080/ 14719037.2019.1619816

49. Durant RF. Agenda setting, the "third wave," and the administrative state. Adm Soc. 1998;30(3):211-247. doi:10.1177/ 0095399798303001

50. Cook BJ. Old and new: privatization and the accountability challenge. Adm Soc. 2018;50(3):319-320. doi:10.1177/ 0095399717754097

51. Ferreira D, Marques R. Public-private partnerships in health care services: do they outperform public hospitals regarding quality and access? Evidence from Portugal. Socioecon Plann Sci. 2021;73:100798. doi:10.1016/j.seps.2020.100798

52. van den Hurk M. Public-private partnerships: where do we go from here? A Belgian perspective. Public Works Manag Policy. 2018;23(3):274-294. doi:10.1177/1087724X18757534

53. Powell M. New private sector providers in the welfare state. Public Adm. 2019;97(1):231-232. doi:10.1111/padm.12581

54. Ylönen M, Kuusela H. Consultocracy and its discontents: a critical typology and a call for a research agenda. Governance. 2019;32(2):241-258. doi:10.1111/gove.12369

55. Miller HT, Simmons JR. The irony of privatization. Adm Soc. 1998;30(5):513-532. doi:10.1177/0095399798305002

56. Couty ES. Pacte de confiance à l'hôpital: Rapport de synthèse. Paris: Ministère chargé de la santé; 2013.

57. Muller ZJ. The Tyranny of Metrics. Princeton; 2018.

58. Math A. Les effets des politiques d'austérité sur les dépenses et services publics de santé en Europe. La Revue de l'Ires. 2017;9192(1):17-47. doi:10.3917/rdli.091.0017

59. World Health Organization. Regional Office for Europe, Health Evidence Network, European Observatory on Health Systems and Policies. Health policy responses to the financial crisis in Europe; 2012. World Health Organization. Regional Office for Europe. ISSN 2077-1584. Available from: https://apps.who.int/iris/handle/ 10665/108608. Accessed June 4, 2021.

60. Karanikolos M, Mladovsky P, Cylus J, et al. Financial crisis, austerity, and health in Europe. Lancet. 2013;381 (9874):1323-1331. doi:10.1016/S0140-6736(13)60102-6

61. Kentikelenis A, Karanikolos M, Reeves A, McKee M, Stuckler D. Greece's health crisis: from austerity to denialism. Lancet. 2014;383 (9918):748-753. doi:10.1016/S0140-6736(13)62291-6

62. Da Silva N. L'impact des conditions macroéconomiques sur l'état de santé. La Revue de l'Ires. 2017;91-92(1):49-75. doi:10.3917/ rdli.091.0049

63. Bécheur H. Hôpital: désolé, on ferme ? Hépato Gastro Oncolog Digest. 2021;28(3):415-417.

64. Mintzberg H. The Structure of Organizations: A Synthesis of the Research. Prentice-Hall; 1979.

65. Simon HA. Bounded Rationality. In Utility and Probability. London: Palgrave Macmillan; 1990: 15-18.

66. Costa-Font J, Greer S, Eds. Federalism and Decentralization in European Health and Social Care. Springer; 2016.

67. Altenstetter C. Insights from health care in Germany. Am J Public Health. 2003;93(1):38-44. doi:10.2105/AJPH.93.1.38
68. Cicchetti A, Gasbarrini A. The healthcare service in Italy: regional variability. Eur Rev Med Pharmacol Sci. 2016;20(1 Suppl):1-3.

69. Ferreira DC, Nunes AM. Technical efficiency of Portuguese public hospitals: a comparative analysis across the five regions of Portugal. Int J Health Plann Manage. 2019;34(1):e411-22. doi:10.1002/hpm.2658

70. Statista. Private healthcare expenditure in the United Kingdom from 1997 to 2018 (In billion GBP); 2020. Available from: https:/www. statista.com/statistics/317868/private-healthcare-expenditure-in-the -united-kingdom-by-sector/. Accessed June 4, 2021.

71. Limb M. Long NHS waiting times are harming patients, MPs warn. BMJ. 2019;12:365.

72. Papanicolas I, Mossialos E, Gundersen A, Woskie L, Jha AK. Performance of UK National Health Service compared with other high income countries: observational study. BMJ. 2019;367. doi: $10.1136 / \mathrm{bmj} .16326$

73. McVeigh TP, Wiggins J, Ward S, Kemp Z, George AJ. Successful repatriation of breast cancer surveillance for high-risk women to the UK National Health Service breast screening programme. Clin Breast Cancer. 2018;18(4):282-288. doi:10.1016/j.clbc.2017.10.015

74. Plimmer G. UK private hospitals suffer as NHS brings work back in house. Financial Times. 2018.

75. Clover B. Private patient unit income hits $£ 360 \mathrm{~m}$ in London. Health Service J. 2020.

76. Duval S. Maltraitances, secret, dénonciation et assistance. Droit Déontologie Soin. 2014;14(1):87-96. doi:10.1016/j. ddes.2014.01.009

77. Blondel B. Les maternités en milieu rural: bénéfices et inconvénients de la fermeture des maternités de proximité. Revue de Médecine Périnatale. 2017;9(3):184-188. doi:10.1007/ s12611-017-0400-5

78. Or Z. Investment in big data; 2015. Available from: https://www. hspm.org/_layouts/livinghit/customforms/dispnews.aspx?id= $27 \&$ site $=$ https://www.hspm.org/countries/france $25062012 \&$ isdlg $=$ 1. Accessed June 4, 2021.

79. Nunes AM, Ferreira DC, Campos Fernandes A. Financial crisis in Portugal: effects in the health care sector. Int J Health Services. 2019;49(2):237-259. doi:10.1177/0020731418822227

80. Vandewattyne J, Cultiaux J, Deruyver R. De La Poste à bpost: histoire d'une mutation (1991-2015). Courrier hebdomadaire du CRISP. 2017;n 2326-2327(1):5-104. doi:10.3917/cris.2326.0005

81. Grimault V. Faut-il enterrer le train? Altern Econom. 2018; $\mathrm{N}^{\circ} 378$ (4):24. doi:10.3917/ae.378.0024

82. Lévy J, Fauchille JN, Póvoas A. Théorie de la justice spatiale: Géographie du juste et de l'injuste. Paris, France: Odile Jacob Publishing House; 2018.

83. Azéma A, Mauhourat MB. L'école rurale, entre tensions territoriales et enjeux scolaires. Admin Educ. 2019;2019(2):41-45.

84. Ryan P. "Technocracy," democracy ... and corruption and trust. Policy Sci. 2018;51(1):131-139. doi:10.1007/s11077-017-9305-1

85. Vermeren P. La France qui déclasse: Les gilets jaunes, une jacquerie au XXIe siècle. France: Tallandier Publisher; 2019.

86. Walhof D. The shadow of unfairness: a plebeian theory of liberal democracy. Contempor Political Theory. 2018;17(S2):62-65. doi:10.1057/s41296-017-0123-1

87. Green JE. The Shadow of Unfairness: A Plebeian Theory of Liberal Democracy. UK: Oxford University Press; 2016.

88. Proudhon PJ. Du principe fédératif et de la nécessité de reconstituer le parti de la révolution par P.-J. Proudhon. E. Dentu; 1863.

89. Rey A, ed. Dictionnaire historique de la langue française (in French). Dictionnaires Le Robert; 1992.

90. Kern A, Hooghe M. The effect of direct democracy on the social stratification of political participation: inequality in democratic fatigue? Compar Eur Politics. 2018;16(4):724-744. doi:10.1057/ s41295-017-0093-y 
91. Fourquet J. « 1985-2017: Quand les classes favorisées ont fait sécession ». Étude de la Fondation Jean Jaurès; 2018.

92. Fourquet J. L'archipel français - Naissance d'une nation multiple et divisée. Paris, France: Le Seuil Publishers; 2019:384.

93. Stewart I. A divided republic: nation, state and citizenship in contemporary France. Eur Rev Hist. 2016;23(1-2):281-283. doi:10.1080/13507486.2015.1099824

94. Al-Matary S. La haine des clercs. Paris, France: Le Seuil; 2019.

95. Devecchio D. Recomposition. Éd. du Cerf; 2019:304.

96. Andolfatto D, Labbé D. Un échec français: la démocratie sociale. Le Débat. 2019;206(4):84-92. doi:10.3917/deba.206.0084

97. Deleuze G. Post Scriptum sur les sociétés de contrôle. Pourparlers, Éditions de Minuit; 1990.

98. Foucault M. Surveiller et punir. Naissance de la prison. Paris: Gallimard Publishers; 2014.
99. Lane JF. From 'moule'to 'modulation': logics of Deleuzean 'control'in recent reforms to French Labour Law. Modern Contemp France. 2018;26(3):245-259. doi:10.1080/09639489.2018.1437126

100. Merlo G, Page K, Ratcliffe J, Halton K, Graves N. Bridging the gap: exploring the barriers to using economic evidence in healthcare decision making and strategies for improving uptake. Appl Health Econ Health Policy. 2015;13(3):303-309. doi:10.1007/ s40258-014-0132-7

101. Matějová L, Nemec J, Křápek M, Klimovský D. Economies of scale on the municipal level: fact or fiction in the Czech Republic? NISPAcee J Public Admin Policy. 2017;10 (1):337-9038. doi:10.1515/nispa-2017-0002

102. Losada C, Albareda A, Longo F, Férez M. Public Employment in Spain: Challenges for the Attainment of a More Efficient, Democratic State. Spain: Esade Publisher; 2017:218.
Risk Management and Healthcare Policy

\section{Publish your work in this journal}

Risk Management and Healthcare Policy is an international, peerreviewed, open access journal focusing on all aspects of public health, policy, and preventative measures to promote good health and improve morbidity and mortality in the population. The journal welcomes submitted papers covering original research, basic science, clinical \& epidemiological studies, reviews and evaluations,

\section{Dovepress}

guidelines, expert opinion and commentary, case reports and extended reports. The manuscript management system is completely online and includes a very quick and fair peer-review system, which is all easy to use. Visit http://www.dovepress.com/testimonials.php to read real quotes from published authors. 